\title{
PERANAN AMRI TAMBUNAN TERHADAP PEMBANGUNAN KABUPATEN DELI SERDANG, 2004-2014
}

\author{
Suriyani Rosa Harahap' ${ }^{1}$, Ricu Sidiq ${ }^{2}$ \\ 1) Alumni Jurusan Pendidikan Sejarah, Universitas Negeri Medan, Indonesia \\ 2) Jurusan Pendidikan Sejarah, Universitas Negeri Medan, Indonesia \\ Corresponding Email: ricusidiq@unimed.ac.id
}

\begin{abstract}
This study aims to determine the role of Amri Tambunan in the period before and after becoming Deli Serdang Regent, knowing the condition of Deli Serdang in the first period 2004-2009, and the second period 2009-2014 during the leadership of Amri Tambunan. This research uses the historical method. Based on the results of the study, it was concluded that Amri Tambunan was known as a North Sumatra figure, among others as the Chairperson of KAPPI Siantar (1964), Deputy Chair of PCNU Deli Serdang (1988), Deputy Chair of North Sumatra PWNU (1999), Chair of the North Sumatra Kepamongan Alumni Family Association (2010 to present), Mustasyar PWNU North Sumatra (2007 to present), and Chairman of the Honorary Board of the North Sumatra Democratic Party (2011-2016). In addition, Amri Tambunan also has a number of achievements in various fields from 2009 to 2013 at national and international levels, such as the Innovative Government Award (IGA) and the Darling Mother and Baby Hospital.
\end{abstract}

Keywords: Amri Tambunan, Regent, Deli Serdang

\begin{abstract}
Abstrak
Penelitian ini bertujuan untuk mengetahui peranan Amri Tambunan pada masa sebelum dan sesudah menjadi Bupati Deli Serdang, mnegetahui kondisi Deli Serdang pada periode pertama 2004-2009, dan periode kedua 2009-2014 semasa kepemimpinan Amri Tambunan. Penelitian ini menggunakan metode sejarah. Berdasarkan hasil penelitian diperoleh kesimpulan bahwa Amri Tambunan dikenal sebagai tokoh Sumatera Utara, antara lain sebagai Ketua KAPPI Siantar (1964), Wakil Ketua PCNU Deli Serdang (1988), Wakil Ketua PWNU Sumatera Utara (1999), Ketua Ikatan Keluarga Alumni Pendidikan Tinggi Kepamongan Sumatera Utara (2010 s/d sekarang), Mustasyar PWNU Sumatera Utara (2007 s/d sekarang), dan Ketua Dewan Kehormatan Partai Demokrat Sumut (2011-2016). Selain itu, Amri Tambunan juga memilik sejumlah prestasi yang diraih di berbagai bidang sejak tahun 2009 hingga 2013 tingkat nasional dan internasional, seperti penghargaan Innovative Government Award (IGA) dan Rumah Sakit Sayang Ibu dan Bayi.
\end{abstract}

Kata Kunci: Amri Tambunan, Bupati, Deli Serdang 


\section{PENDAHULUAN}

Kepala daerah memiliki peran yang sangat strategis karena memiliki pengaruh yang signifikan bagi pencapaian keberhasilan pembangunan nasional. Ketidakmampuan kepala daerah untuk melakukan tugas pokok dan fungsi tentu akan berakibat fatal bagi daerah tersebut, dan juga bagi pembangunan nasional karena pembangunan nasional ditentukan oleh seberapa berhasilnya pembangunan di daerah. Dengan kata lain, arah dan tujuan organisasi pemerintahan daerah ditentukan oleh kemampuan, kompetensi dan kappabilitas kepala daerah dalam melaksanakan fungsi-fungsi administrasi atau manajerial, kepemimpinan, pembinaan dan pelayanan, serta tugas-tugas lain yang menjadi kewajiban dan tanggung jawab kepala daerah (Kaloh, 2003: 4). Kemampuan ini jelas tergambar dari sosok Amri Tambunan yang merupakan Bupati Kabupaten Deli Serdang. Selama ia menjabat sebagai bupati, Amri Tambunan memiliki berbagai program dan prestasi yang berdampak terhadap kemajuan Deli Serdang.

Pada masa kepemimpinan Amri Tambunan, Pemerintah Kabupaten Deli Serdang menetapkan tiga prioritas pembangunan yaitu sektor pendidikan, kesehatan dan infrastruktur.

Program-program yang ditawarkan oleh Amri Tambunan pada masa ke-pemimpinannya tentu memiliki dampak yang sangat besar dari segi infrastruktur dan pendidikan serta kesehatan Deli Serdang hari ini. Dan tidak dapat di pungkiri lagi bahwa sosok Amri Tambunan tentu sangat membekas di mata masyarakat Deli Serdang. Berdasarkan latar belakang di atas, penelitian ini mengkaji tentang kehidupan Amri Tambunan sebelum dan sesudah menjadi Bupati, serta kondisi Deli Serdang pada masa kepemimpinan Amri Tambunan.

\section{METODE PENELITIAN}

Setiap penulisan membutuhkan metode ataupun cara-cara prosedur dan teknik untuk mencapai tujuan penelitian tersebut. Metode penelitian yang digunakan oleh peneliti dalam penelitian berjudul "Peranan Amri Tambunan Terhadap Pembangunan Kabupaten Deli Serdang 20042014" adalah metode sejarah.

Gottschalk dalam buku yang berjudul "Mengerti Sejarah" menuliskan mengenai pengertian metode sejarah: "metode sejarah adalah proses menguji dan menganalisa secara rekaman dan peninggalan masa lampau. Rekonstruksi yang imajinatif dari masa lampau berdasarkan data yang diperoleh dengan menempuh proses disebut historiografi (penulisan sejarah). Dengan mempergunakan metode sejarah dan historiografi (yang sering dipersatukan dengan nama metode sejarah) sejarawan berusaha untuk merekonstruksi sebanyak-banyaknya dari pada masa lampau manusia (Gottschlak, 2008: 39).

\section{HASIL DAN PEMBAHASAN Gambaran Umum Kabupaten Deli Serdang}

Pada masa awal pemerintahannya, Kota Medan menjadi pusat pemerintahan. Hal ini dikarenakan dalam sejarahnya sebagian besar wilayah Kota Medan adalah "tanah Deli" yang merupakan daerah Kabupaten Deli Serdang. Sekitar tahun 1980-an, pemerintahan daerah ini pindah ke Lubuk Pakam, sebuah kota kecil yang terletak di pinggir Jalan Lintas Sumatera lebih kurang 30 kilometer dari kota Medan yang telah ditetapkan menjadi ibukota Kabupaten Deli Serdang.

Pada tahun 2004, kabupaten ini kembali mengalami perubahan baik secara geografis maupun administrasi pemerintahan, setelah adanya pemekaran daerah dengan lahirnya kabupaten baru Serdang Bedagai sesuai dengan Undang-Undang No. 36 Tahun 2003, sehingga berbagai potensi daerah yang dimiliki ikut berpengaruh. Dengan terjadinya pemekaran daerah, maka luas wilayahnya sekarang menjadi $2.497,72 \mathrm{~km}^{2}$ yang terdiri dari 22 kecamatan dan 403 desa, yang terhampar mencapai 3.34\% dari luas Sumatera Utara. 


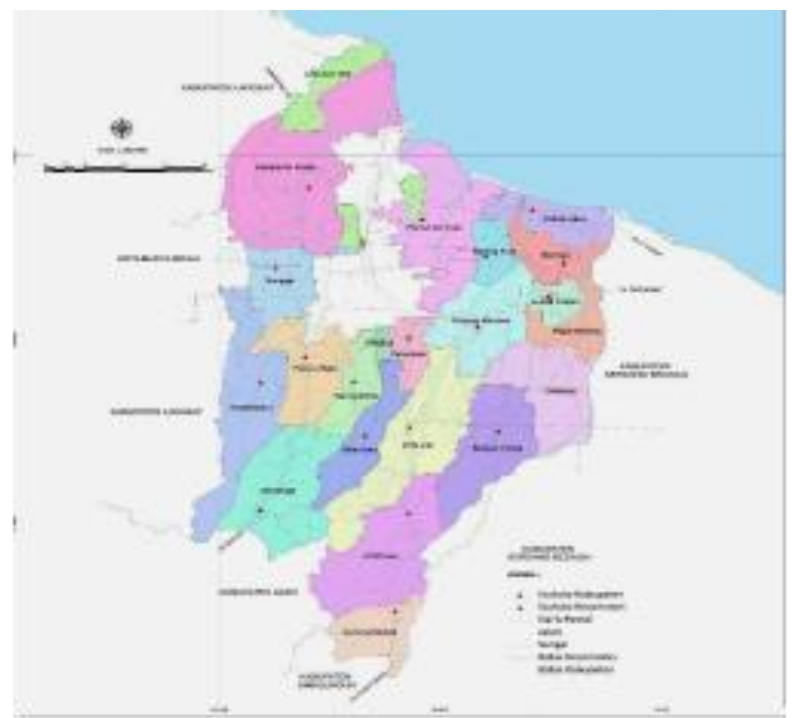

Gambar 1. Peta Kabupaten Deli Serdang Sumber: BPS Kabupaten Deli Serdang, (2011)

Kabupaten Deli Serdang dihuni penduduk yang terdiri dari berbagai suku bangsa seperti Melayu, Karo, Simalungun, Jawa, Batak, Minang, Cina, Aceh dan pemeluk berbagai agama seperti Islam, Kristen, Hindu dan Budha, dengan keseluruhan penduduk berjumlah 1.686.366 jiwa dengan laju pertumbuhan penduduknya sebesar $2,74 \%$ dengan kepadatan rata-rata 616 jiwa perkilometer persegi.

\section{Latar Belakang Amri Tambunan}

Amri Tambunan dilahirkan dari sosok keluarga pejuang Bapak Mayor (T) H. Djamaluddin Tambunan (alm) dan Ibu Lettu Hj. Nubanum Siregar (almh) yang keduanya dimakamkan di Taman Makam Pahlawan Medan.

Amri Tambunan dilahirkan pada tanggal 23 Januari 1949 dalam kondisi bangsa Indonesia mengalami tantangan besar akibat adanya upaya penjajah untuk kembali menjajah Indonesia, Nurbanun harus berkali-kali mengungsi karena tekanan bangsa penjajah. Dalam kandungan, Amri Tambunan sudah merasakan pahit getirnya hidup di pengungsian. Bahkan pada saat hamil tua, Nurbanun ditangkap dan ditawan Belanda di Tanjungbalai untuk memaksa agar suaminya Mayor Djamaluddin Tambunan yang berjuang melawan Belanda menyerahkan diri kepada penjajah.

Meski melahirkan di rumah sakit dalam kondisi sebagai tawanan Belanda, Nurbanun dan bayinya berhasil melarikan diri dengan bantuan para pejuang. Berhari-hari Nurbanun harus menggendong Amri kecil berjalan kaki keluar masuk hutan menghindari kejaran Belanda. Perjuangan berat sewaktu kecil inilah yang kiranya membuat sosok Amri Tambunan menjadi seorang pribadi yang tangguh, tegas dan berwibawa.

Amri Tambunan dilahirkan sebagai anak kedua, sebelumnya pasangan ini telah dianugerahi seorang anak perempuan yang diberi nama Irma. Namun karena sulitnya kehidupan pada waktu itu karena terus dikejar-kejar Belanda, mereka harus sering berpindah tempat dan mengungsi bahkan sampai ke Padangsidempuan. Akibatnya, Irma yang baru berusia empat bulan itu tak mampu bertahan dan meninggal dunia di pengungsian dan kelahiran Amri menjadi penawar kesedihan mereka.

Pendidikan dasar dijalani Amri Tambunan di Pematang Siantar dan tamat SD tahun 1961, kemudian melanjutkan ke SMPN 1 Medan. Pendidikan di bangku SMA dijalani Amri di tiga sekolah, yaitu kelas 1 di SMA Negeri 1 Medan, kelas 2 di SMA Negeri 1 Sipirok dan kelas 3 di SMA Negeri 2 Pematang Siantar. Sempat menuntut ilmu di Fakultas Teknik USU, tapi kemudian memilih menekuni ilmu pemerintahan di APDN Medan dan terus melanjutkan ke IIP Jakarta.

Suasana yang penuh perjuangan itulah yang nampaknya mewarnai sosok Pak Amri yang berani, tegas, bersahaja dan santun sehingga sangat dekat dengan rakyat. Berikut riwayat jabatan yang diemban Amri Tambunan:

1. Kaur Pembinaan Masyarakat Kantor Camat Medan Johor (1979-1981)

2. Camat Tanjung Morawa (1984-1988) 
3. Asisten II Setwilda Tk. II Deliserdang (1988-1995)

4. Pembantu Bupati Deli Serdang Wilayah IV (1995-1997)

5. Kepala Subdis Retribusi Dispenda Tk. I SU (1997)

6. Kepala Biro Humas Setdasu (1997-1999)

7. Sekretaris Daerah Kota Medan (1999-2002)

8. Kepala Badan Informasi dan Komunikasi Provsu (2002-2004)

9. Bupati Deli Serdang (2004-2009, 20092014)

Dari hasil wawancara dengan Istri bapak Amri Tambunan yaitu Ibu Anita Lubis (50 tahun), beliau mengatakan, "selain sebagai suami, ayah dari anak-anak, bapak Amri merupakan sosok yang visioner, yang mengabdikan seluruh ilmu dan baktinya untuk perkembangan dan kesejahteraan masyarakat. Dalam perjuangan Bapak Amri, Ibu Anita menjadi saksi betapa kerasnya perjuangan sosok Mantan Bupati tersebut, mulai dari pegawai kantor lurah, Camat Tanjung Morawa, Pembantu Bupati hingga sosok panutan yang memajukan Kabupaten Deli Serdang dengan ide-ide cemerlangnya" (Wawancara Anita Lubis, November 2018). Amri Tambunan sukses terpilih menjadi Bupati Deli Serdang periode 2004-2009. Kemudian melanjutkan periode berikutnya 2009-2014. Almarhum adalah tokoh Sumut yang banyak memberikan kontribusi dalam bidang pembangunan. Dalam bidang kemasyarakatan, ia juga malang melintang di antaranya Ketua KAPPI Siantar (1964), Wakil Ketua PCNU Sumut (1988), Wakil Ketua PWNU (1999), Ketua IKAPTI dan sejumlah organisasi lainnya.

Dari hasil wawancara dengan Bapak Ashari Tambunan (62), adik kandung dari Bapak Amri Tambunan, beliau mengatakan bahwa "Bapak Amri merupakan sosok yang baik, dan melindungi secara khusus sebagai seorang kakak, mengajarkan dan mendidik untuk menjadi sosok yang berguna. Beliau mengatakan, asal mula pencalonan bapak Amri menjadi bupati, beliau ragu dengan dukungan masyarakat. Namun setelah terjun langsung ke lapangan beliau mendapati dukungan yang luar biasa dari masyarakat luas" (Wawancara Ashari Tambunan, November 2018).

Keperdulian kepada berbagai etnis membuatnya sangat dekat dengan masya-rakat, dan mendapat berbagai gelar kehormatan, diantaranya dari masyarakat Jawa di Percut, marga Sembiring dari masyarakat Karo di Gunung Meriah, dan gelar Datuk Utama Wirawangsa dari etnis Melayu.

Amri Tambunan dikaruniai 4 orang anak, 3 orang dari pernikahan dengan Almarhumah $\mathrm{Hj}$ Farida Siregar (meninggal tahun 2000), yaitu dr. Asri Ludin Tambunan, Rudi Akmal Tambunan, Anita Irma Tambunan, dan seorang putri bernama Karisa Putri Tambunan dari pernikahannya dengan Anita Lubis pada tahun 2002.

\section{Amri Tambunan dan Pembangunan Deli Serdang (2004-2009)}

Amri Tambunan adalah figur yang sudah lama dikenal di tengah-tengah masyarakat Sumatera Utara. Bukan hanya sebagai Bupati Deli Serdang saja, lebih dari itu, Amri merupakan birokrat sejati yang berhasil sukses dengan kerja keras. Beliau adalah Bupati Kabupaten Deli Serdang periode pertama dan kedua. Ia merupakan salah satu pemimpin yang perduli pada rakyatnya, banyak program-program beliau yang sudah dijalankan.

Keberhasilan Amri Tambunan dapat dilihat dari pembangunan infrastruktur jalan. Sebelum tahun 2004, jalan di Kabupaten Deli Serdang hanya mampu menerobos sejauh $1.317,6 \mathrm{~km}^{2}$. Namun sejak Amri dipercaya menjabat Bupati Deli Serdang, panjang jalan sudah menembus hingga mencapai $3.372,92 \mathrm{~km}^{2}$. Begitu juga dengan pembangunan jembatan hingga kini telah mencapai $13.677,95 \mathrm{~m}$ dengan jumlah 4.096 unit.

Dalam gerak pembangunannya, motto Kabupaten Deli Serdang yang tercantum dalam lambang daerahnya adalah "Bhinneka Perkasa 
Jaya" yang memberi pengertian; dengan masyarakatnya yang beraneka ragam suku, agama, ras dan golongan bersatu dalam kebhinnekaan secara kekeluargaan dan gotong royong membangun semangat kebersamaan, menggali dan mengembangkan potensi sumber daya alam dan sumber daya manusianya sehingga menjadi kekuatan dan keperkasaan untuk mengantarkan masyarakat kepada kesejahteraan dan kejayaan sepanjang masa.

Untuk memacu laju percepatan pembangunan, Pemkab Deli Serdang menetapkan tiga prioritas pembangunan yaitu sektor pendidikan, kesehatan dan infrastruktur tanpa mengabaikan sektor lainnya. Gerakan Deli Serdang Membangun (GDSM) yang dicanangkan Amri Tambunan mengusung konsep kebersamaan dan semangat kegotongroyongan antar tiga pilar, artinya percepatan pembangunan yang selama ini dilaksanakan mengandalkan tiga pilar, yakni pemerintah, dukungan pihak swasta dan partisipasi masyarakat. Program yang menyinergikan tiga pilar kekuatan pembangunan itu berhasil mendongkrak percepatan pembangunan, terutama pada prioritas pembangunan, yakni infrastruktur, pendidikan, dan kesehatan dengan tidak mengabaikan sektor-sektor lainya.

Di bidang pendidikan, Amri Tambunan berhasil merehab 621 unit gedung SD Negeri yang mengalami kerusakan berat melalui pola kebersamaan dengan menggalang kekuatan tiga pilar pembangunan daerah yakni pemerintah, partisipasi masyarakat dan dukungan sektor swasta. Konsep ini dikenal dengan sebutan "CERDAS" (Percepatan Rehabilitasi dan Apresiasi terhadap Sekolah). Dalam kurun waktu 2 tahun (2005-2007), Kabupaten Deli Serdang bebas dari sekolah yang tidak layak pakai.

Di sektor kesehatan, Amri Tambunan mewujudkannya melalui program "CERIA" (Percepatan Penurunan Kematian Ibu dan Anak). Ide konsep ini merupakan suatu gerakan dalam upaya mendorong pemberdayaan perempuan, keluarga dan masyarakat. Grand strategi yang diterapkan untuk mencapai hal tersebut di- lakukan lewat Forum Komunikasi Perubahan Perilaku (FKPP). Selain membangun Puskesdes sebagai sarana terdekat dalam memberi pelayanan kepada masyarakat, keberadaan Puskesmas telah ditingkatkan menjadi Puskesmas rawat inap. Semua ide maupun program yang digulirkan mendapat respon dan telah membuahkan hasil optimal dan dirasakan seluruh lapisan masyarakat hingga ke pedesaan.

Dalam upaya mendekatkan pelayanan kesehatan kepada masyarakat, dari 33 Puskesmas yang tersebar di seluruh kecamatan, sebanyak 17 Puskesmas telah ditingkatkan statusnya menjadi Puskesmas Rawat Inap. Begitu juga pembangunan Puskesmas Pembantu yang jumlahnya kini mencapai 104 unit serta Poskesdes dengan jumlah 150 unit.

Pada sektor Pariwisata juga menjadi sebuah harapan yang besar bagi Deli Serdang yang memiliki tempat-tempat objek wisata yang tidak kalah dengan daerah lainnya di Sumatera Utara. Demikian juga wisata bahari, adanya tempat rekreasi yang nyaman seperti "Siba Island" di Kecamatan Hamparan Perak.

Sejalan dengan pengembangan pariwisata, Khusus untuk pengembangan sektor industri kecil dan rumah tangga, pembinaannya dilakukan secara intensif melalui Dekranasda antara lain peningkatan produksi kain tenun dan kerajinan rakyat yang telah berhasil menembus pasar dalam dan luar negeri.

Sejalan dengan program GDSM yang terus bergulir, pada sektor pembangunan pertanian tercatat berbagai pencapaian hasil yang cukup signifikan antara lain peningkatan hasil produksi padi dari 382,737 ton tahun 2008 naik menjadi 391.623 ton tahun 2009 dengan luas panen dari 73.812 ha menjadi 75.534 ha.

Pada tahun 2009, Amri Tambunan terpilih kembali menjadi Bupati Kabupaten Deli Serdang periode 2009-2014. Kepiawaian Amri Tambunan dalam memimpin Kabupaten Deli Serdang selama periode pertama ini menjadikannya tepat dan patut berlanjut dua periode. Baginya, perjuangan mengisi kemerdekaan 
bangsa ini merupakan panggilan hati nuraninya untuk menebus pengorbanan para pejuang dan pahlawan yang mengorbankan segalanya bagi kemerdekaan bangsa ini. Hal inilah yang mengantarkan beliau menjadi orang pertama yang berhasil menduduki jabatan Bupati Deli Serdang dua periode (Stiven, 2013: 14).

Keberhasilan Amri Tambunan menjadi alasan masyarakat untuk memilihnya kembali sebagai Bupati. Di Sumatera Utara, ia memenangkan lebih $50 \%$ suara dan ini baru terjadi dalam Pilkada Sumatera Utara.

\section{Kiprah Amri Tambunan Diperiode Kedua Kepemimpinannya}

Masih mengandalkan dukungan swasta dan partisipasi masyarakat, 1 Maret 2011, beliau kembali mencanangkan satu gebrakan dan inovasi besar. Terobosan ini merupakan gerakan moral dan kemanusiaan yang dikenal dengan "Gerakan Bedah Rumah". Hasilnya hingga kini sudah 1.300 lebih rumah tidak layak huni yang tersebar di seluruh pelosok Deli Serdang telah menjelma menjadi rumah layak huni. Diharapkan pada tahun 2014 nanti tidak ada lagi rumah tidak layak huni di Kabupaten Deli Serdang.

Dengan berbagai inovasi dan kebijakannya dalam memacu percepatan pembangunan, Amri sebagai bupati sukses menekan angka kemiskinan. Kini Deli Serdang merupakan kabupaten yang paling rendah angka kemiskinannya, hanya 5,34\% (BPS Kabupaten Deli Serdang, 2011).

Kepedulian dan komitmen Amri Tambunan dalam membangun sektor pertanian, dapat dilihat dari fakta pada bulan Desember 2011 yang lalu, beliau menerima penghargaan Adhikarya Pangan Nusantara (APN) dari Presiden RI.

Suatu hal yang patut dibanggakan adalah penghargaan Peningkatan Produksi Beras Nasional (P2BN) dari Presiden RI Susilo Bambang Yudhoyono kepada Amri Tambunan pertengahan Juli 2012. Penghargaan itu diberikan karena Kabupaten Deli Serdang berhasil meningkatkan produksi padinya sebesar $20,68 \%$ jauh di atas target yang ditetapkan pemerintah sebesar $5 \%$. Di bidang olahraga, PSDS Junior baru saja menorehkan Tinta Emas menjadi Juara Nasional (Piala Suratin 2012) setelah SUMUT minus Prestasi Tingkat Nasional selama puluhan tahun.

Pembangunan kesehatan di Kabupaten Deli Serdang juga tidak dilupakan oleh Amri Tambunan. Beliau telah berhasil menyediakan sarana dan prasarana pelayanan kesehatan masyarakat (Puskesmas, Puskesmas Pembantu dan Pos Kesehatan Desa) di setiap kecamatan. Di samping itu pula telah tersedia sebanyak 15 unit rumah sakit yakni 4 unit di Kecamatan Tanjung Morawa, 3 unit di Lubuk Pakam, 3 unit di Deli Tua, 3 unit di Percut Sei Tuan, 1 unit di Labuhan Deli dan 1 unit di Sunggal.

Untuk melaksanakan pelayanan kesehatan dasar, pada tahun 2008 di Kabupaten Deli Serdang telah tersedia 32 unit Puskesmas (13 unit Puskesmas Rawat Inap dan 19 Puskesmas Rawat Jalan), 103 unit Puskesmas Pembantu dan 95 unit Pos Kesehatan Desa. Ratio antara jumlah Puskesmas terhadap jumlah penduduk sekitar 1:54.326, sedangkan ratio Puskesmas Pembantu terhadap jumlah penduduk adalah 1:16.878.

Masalah yang dijumpai dalam pelayanan kesehatan dasar adalah rendahnya tingkat utilitas dan kualitas pelayanan kesehatan. Hal ini diikuti dengan peningkatan sarana pendukung pelayanan kesehatan yaitu 18 unit peralatan laboratorium lengkap, 32 unit.

Puskesmas Keliling beroda empat, 104 Patroli kesehatan roda dua, 1 unit mobil promosi kesehatan, 1 unit ambulans gawat darurat penanggulangan bencana dan penyakit menular dan 34 unit mesin fogging. Sedangkan untuk pelayanan rujukan terdapat 1 unit rumah sakit pemerintah dan 14 unit rumah sakit swasta.

Selain itu Upaya Kesehatan Berbasis Masyarakat (UKBM) telah membuahkan hasil yang dapat dilihat dari partisipasi masyarakat dalam penyediaan lahan untuk pembangunan 95 unit Pos Kesehatan Desa (Poskesdes) dan adanya 1.367 Pos Pelayanan Terpadu (Posyandu) hasil partisipasi masyarakat. 


\section{SIMPULAN}

Kepemimpinan Amri Tambunan didasari oleh kerja keras dan semangat untuk membangun Deli Serdang. Berbagai upaya telah dilakukannya untuk membangun Deli Serdang. Meskipun Amri Tambunan lebih memfokuskan pada tiga sektor pembangunan yaitu pendidikan, kesehatan dan infrastruktur, namun pembangunan di sektor lain tetap dilaksanakan. Hal ini terbukti dengan me-ningkatnya produksi pertanian dan industri pariwisata di Kabupaten Deli Serdang.

\section{REFERENSI}

BPS Kabupaten Deli Serdang. (2011). Deli Serdang dalam Angka 2011. Deli Serdang: BPS Kabupaten Deli Serdang.

Gottschlak, L. (2008). Mengerti Sejarah. Jakarta: Yayasan Penerbit UI.

Kaloh, J. (2003). Kepala Daerah Pola Kegiatan, Kekuasaan dan Perilaku Kepala Daerah dalam Pelaksanaan Otonomi Daerah. Jakarta: Gramedia Pustaka Utama.

Stiven, K. (2013). Biografi Drs H. Amri Tambunan. Deli Serdang: Tanpa penerbit.

Wawancara Anita Lubis di Lubuk Pakam, Deli Serdang, November 2018.

Wawancara Ashari Tambunan di Lubuk Pakam, Deli Serdang, November 2018. 